\title{
Peracarid fauna (Crustacea, Malacostraca) of the Northeast Water Polynya off Greenland: documenting close benthic-pelagic coupling in the Westwind Trough
}

\author{
Angelika Brandt \\ Institute for Polar Ecology, University of Kiel, Seefischmarkt, Geb. 12, Wischhofstr. 1-3, D-24148 Kiel, Germany
}

\begin{abstract}
Composition, abundance, and diversity of peracarids (Crustacea) were investigated over a period of 3 mo in the Northeast Water Polynya (NEW), off Greenland. Samples were collected from May to July 1993 during expeditions ARK IX/2 and 3 using an epibenthic sledge on RV 'Polarstern' Within the macrobenthic community peracarids were an important component of the shelf fauna and accurred in high abundance in this area together with polychaetes, molluscs and brittle stars. A total of 38322 specimens were sampled from 22 stations. Cumacea attained the highest total abundance and Amphipoda the highest diversity. Isopoda were of medium abundance, Mysidacea less abundant, and Tanaidacea least abundant. In total 229 species were found. Differences in composition, abundance and diversity do not reflect bathymetric gradients, but mainly the availability of food (phytoplankton and especially ice algae) and, hence, the temporal and spatial opening of the polynya. Thus primary production and hydrographic conditions (lateral advection due to the anticyclonic gyre around Belgica Bank) are the main biological and physical parameters influencing the peracarid crustacean community, documenting a close coupling between primary production and the benthic community in the eastern Westwind Trough. The high abundance of Peracarida, which are also capable of burrowing in the upper sediment layers, indicates their importance for benthic carbon cycling
\end{abstract}

KEY WORDS: Crustacea Peracarida - Greenland - Northeast Water Polynya - Abundance - Diversity . Benthic-pelagic coupling

\section{INTRODUCTION}

The hydrography of the northeastern Greenland Sea is strongly influenced by the cold polar water flowing from the Arctic Ocean along the Greenland coast to the south (Machoczek 1989, Birgisdottir 1990). The environmental conditions are characterized by very low, but relatively constant, water temperatures, long periods of ice cover, large seasonal fluctuations in light regime and, hence, generally only low biological activity (Hempel 1985). However, recent investigations have shown that benthic communities can be surprisingly rich in both biomass and diversity at various locations on the Greenland Shelf, as well as on the continental and mid-ocean ridge slopes (Piepenburg 1988, Svavarsson et al. 1990, Brandt 1993, Brandt \& Piepenburg 1994, Piepenburg \& von Juterzenka 1994). These communities are thought to be maintained by the temporarily high surplus of sympagic and/or pelagic production associated with nearby marginal ice zones of the East Greenland Current or of polynya regions.

Direct observations of seasonally sedimented fresh phytodetritus in the deep sea have been made (Billett et al. 1983) and primarily pulsed sedimentation events of organic material from the ice edges or open water to the bottom have been postulated (Hebbeln \& Wefer 1991). The seasonal input of organic carbon has a direct effect on benthic communities (Suess 1980 , Grebmeier et al. 1988, Graf 1989, 1992, Carey 1991). The bulk of suspended matter is accumulated in the benthic nepheloid layer (BNL) and advected, mostly by topographically driven currents in certain depth zones, to the areas of eventual deposition (Wainwright 1990 Graf 1992). 
To assess the hypothetical relationship between quality and quantity of sedimentation and benthic response, a mesoscale study was undertaken in the Northeast Water (NEW) Polynya (Deming 1993, Hirche \& Kattner 1994). The study was carried out by an international team, part of which was a group working for a multidisciplinary research programme (Sonderforschungsbereich 313 of the University of Kiel). A major objective of our programme is to assess the interrelationships between benthic community patterns and particle flux between sea floor, sediment-water interface and near bottom BNL (Graf 1992). Benthic and

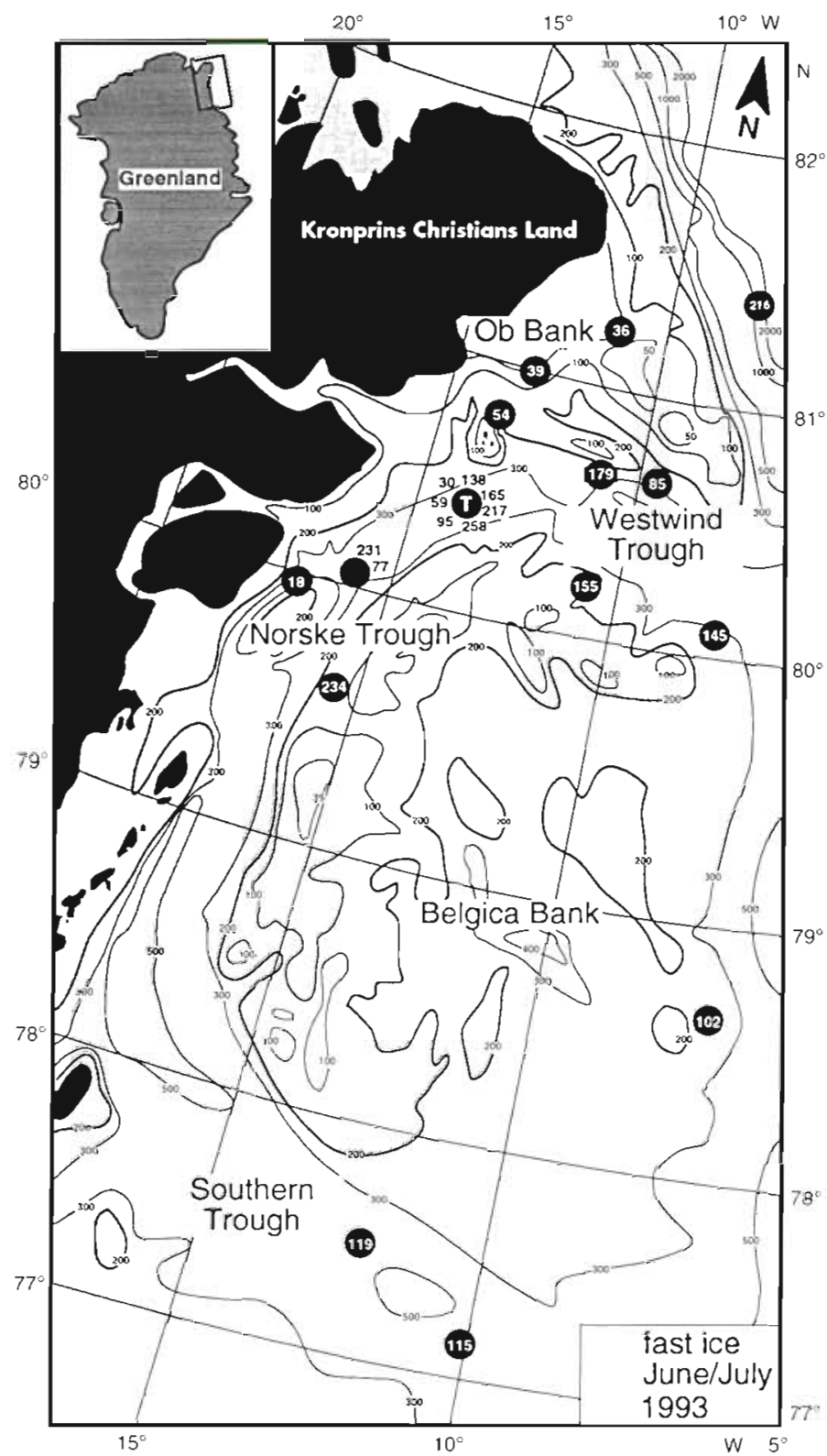

Fig. 1 Schematic illustration of the Northeast Water Polynya with the approximate positions of the stations sampled during 'Polarstern' ARK IX/2 and 3. T: time series stations epibenthic mega- and macrofaunal organisms may play an important role in this feedback system although their abundance is lower than that of meiobenthos. Nonetheless, the impact of these animals on the microscale environment through bioturbation, bio-irrigation, habitat diversification, etc., is substantial (Gage \& Tyler 1991, Romero-Wetzel \& Gerlach 1991, Barthel 1992). However, the smaller macrofauna have been neglected in the methodological approach of many previous investigations, mainly because of small sample sizes and high diversity of taxa: until now most investigations on smaller peracarids were done on the basis of box-core samples, which cover only $0.25 \mathrm{~m}^{2}$. As peracarids have quite a patchy distribution, depending on food availability (Brandt 1993), this device does not produce an accurate sample of the animals occurring in an area. Moreover, due to the wave preceding the box corer, many of the light animals on the surface of the sediment are swept away before the box corer hits the bottom.

Epi-and suprafaunal peracarid crustaceans, in terms of abundance and burrowing behaviour of many species, are presumed to contribute significantly to biogenic modification (bioturbation, bioresuspension) and particle flux in the benthic realm (Brandt 1993, Svavarsson et al. 1993). The peracarid crustaceans Amphipoda, Cumacea, Isopoda, Mysidacea and Tanaidacea are common and important macrobenthic animals occurring from shallow habitats to the abyssal plains of the world oceans in high abundance and diversity (Grassle \& Maciolek 1992). The present study on composition, abundance, and diversity of peracarid crustaceans aims to investigate what influence the polynya has on the epibenthic peracarid community

\section{MATERIALS AND METHODS}

Study area. The NEW Polynya refers to a more or less ice-free area south of Kronprins Christian Land (Nordostrundingen) on the east coast of Greenland (Fig. 1), and is regarded as the northernmost of a number of polynyas occurring along this coast (Vinje 1970 , 1984). Waters south of Nordostrundingen open annually and have been reported to do so since at least the beginning of the present century (Koch 1945). The NEW Polynya can cover 40000 to $44000 \mathrm{~km}^{2}$ (Wadhams 1981, Parkinson et al. 1987, Schneider \& Budéus 1994). It begins to open in April or May, persists throughout the summer and starts closing in September. Originally it was assumed that the NEW Polynya was a latent heat polynya (Smith et al. 1990), where warmer waters in the deeper layers of the NEW Polynya possibly contribute to its opening (Wadhams 1981). Recent investigations, however, indicate a 
northward flow, part of an anticyclonic gyre around Belgica Bank (Bourke et al. 1987, Schneider \& Budeus 1994, Rumohr pers. comm.), instead of an overall southward circulation along the coast. The NEW Polynya mainly covers the northern part of Belgica Bank. The latter has a complicated topography. Its structure is dominated by a trough system (Belgica Trough, Westwind Trough and Norske Trough; Fig. 1) around the central bank. On the banks depths can be as shallow as $60 \mathrm{~m}$, in the trough system more than $300 \mathrm{~m}$, but rarely exceeding $500 \mathrm{~m}$ (Schneider \& Budéus 1994). To the north the NEW Polynya is bordered by Kronprins Christian Land, Nordostrundingen and the Ob Bank. The northern Greenland continental shelf is narrow. The western part of the NEW Polynya extends into 2 valleys, the northern Ingolfsfjord and the more southerly Dijmphna Sund. South of these over the Norske Trough at about $79^{\circ} \mathrm{N}$, a distinct extension of fast ice is present, possibly grounded in the extremely shallow surroundings on the Belgica Bank (Schneider \& Budéus 1994).

A strong vertical density gradient exists between the 2 main water layers. The upper cold, fresh Polar Water (PW) (Bourke et al. 1987, Budéus et al. 1993) extends to about $100 \mathrm{~m}$ depth and is characterized by a salinity of 34.4 (Hopkins 1991). Underneath this layer the water is slightly warmer and more saline. A gradual rise in temperature and salinity occurs with increasing depth to about 0.7 to $0.8^{\circ} \mathrm{C}$ and 34.8 respectively (Fig. 4 in Schneider \& Budéus 1994). Conditions below $300 \mathrm{~m}$ are almost homogenous (Schneider \& Budéus 1994). This fairly stable vertical layering is probably due to both melting of sea ice and runoff from land. Schneider \& Budéus (1994) postulate development of plankton blooms, especially in the northern part of the NEW Polynya. Recent work on board the German research vessel 'Polarstern' revealed that pelagic and benthic biomass were higher in the polynya than in the surrounding area (Hirche \& Bohrer 1987, Piepenburg 1988, Hirche et al. 1991, this study)

Sampling. Material was collected in the NEW Polynya (Fig. 1) off Greenland during RV 'Polarstern' expeditions ARK IX/2 and 3 from May to late July 1993 (for exact data see station list, see Table 1). We employed an epibenthic sledge (EBS) (Rothlishberg \& Pearcy 1977), modified after Buhl-Jensen (1986) and Brattegard \& Fossă (1991). This carries a sampling box in the middle of the frame. The opening is $100 \mathrm{~cm}$ wide and $33 \mathrm{~cm}$ high and extends from 27 to $60 \mathrm{~cm}$ above the bottom. A plankton net of $0.5 \mathrm{~mm}$ mesh size is attached, the cod end of which is enclosed by a $0.3 \mathrm{~mm}$ mesh net. When the sledge touches bottom, a shoe fixed to the box door opens the door. The door is closed by means of springs when the sledge leaves the sea floor. In addition to the EBS, a CTD, Agassiz trawl, box corer, multicorer, bottom-water sampler and bongo net were employed at almost all stations where the EBS was used. The deployment of this gear provided measures of environmental parameters, which helped to explain the variation in abundance and diversity at the different stations (Ahrens 1994, Ritzrau 1994, Graf \& Scheltz pers. comm.).

Although the sledge was designed to sample the water column just above the sediment, observations by scuba divers have revealed that water below the opening is also sampled because of turbulence in front of the gear (Buhl-Jensen 1986). This explains the high percentage of epifauna, which constitute the bulk of the samples.

Usually the sledge was hauled over the ground for 10 min at a mean velocity of 1 knot. The haul distances were calculated on the basis of the GPS-derived positions of the ship at the start and end of the haul as:

$$
\text { Distance }(m)=1852 \sqrt{\left(\Delta \text { lat }^{\prime}\right)^{2}+\left(\cos \text { lat } \times \Delta \text { long }^{\prime}\right)^{2}}
$$

(after Brattegard 1993, Brandt pers comm.).

Area swept was calculated by multiplying the distance travelled by the area of the box opening. As the distances sampled varied from 289 to $489 \mathrm{~m}$ (Table 1), numbers of specimens and species were calculated for a standardized $1000 \mathrm{~m}$ haul (Table 2) (Basford et al. 1989, Svavarsson et al. 1990, Brandt 1993). Positions of EBS sampled stations are shown in Fig 1 and Table 1. The time series stations (T) were visited 7 times at approximately $10 \mathrm{~d}$ intervals during the $3 \mathrm{mo}$. The EBS catches at Stns 30 and 59 (both T-stations) were not quantitative. The qualitative data are considered in the results (see Tables $2 \& 3$ ) but not presented in figures or station analyses.

When the sledge reached the deck of the vessel, samples were suspended, decanted through a $0.3 \mathrm{~mm}$ screen and preserved in $4 \%$ buffered formaldehyde solution. After $3 \mathrm{~d}$ the samples were washed and transferred into $70 \%$ ethanol. For comparison of fauna from the 22 stations the complete samples were analysed.

Data analysis. The abundance and diversity data of the peracarid crustacean species caught are summarized in Tables $2 \& 3$. For differentiation of distinct species assemblages at stations, according to the pattern of their co-occurrences (R-mode), an explorative statistical approach as proposed by Field et al. (1982) was applied. The multivariate data set was subjected to both classification and ordination analyses, i.e. agglomerative hierarchical cluster analysis (Romesburg 1984, Piepenburg \& Piatkowski 1992) and non-metric multidimensional scaling (MDS; Kruskal \& Wish 1978 , Wilkinson 1987), respectively.

The Bray-Curtis coefficient (Bray \& Curtis 1957) was used as a parameter of species distribution resem- 


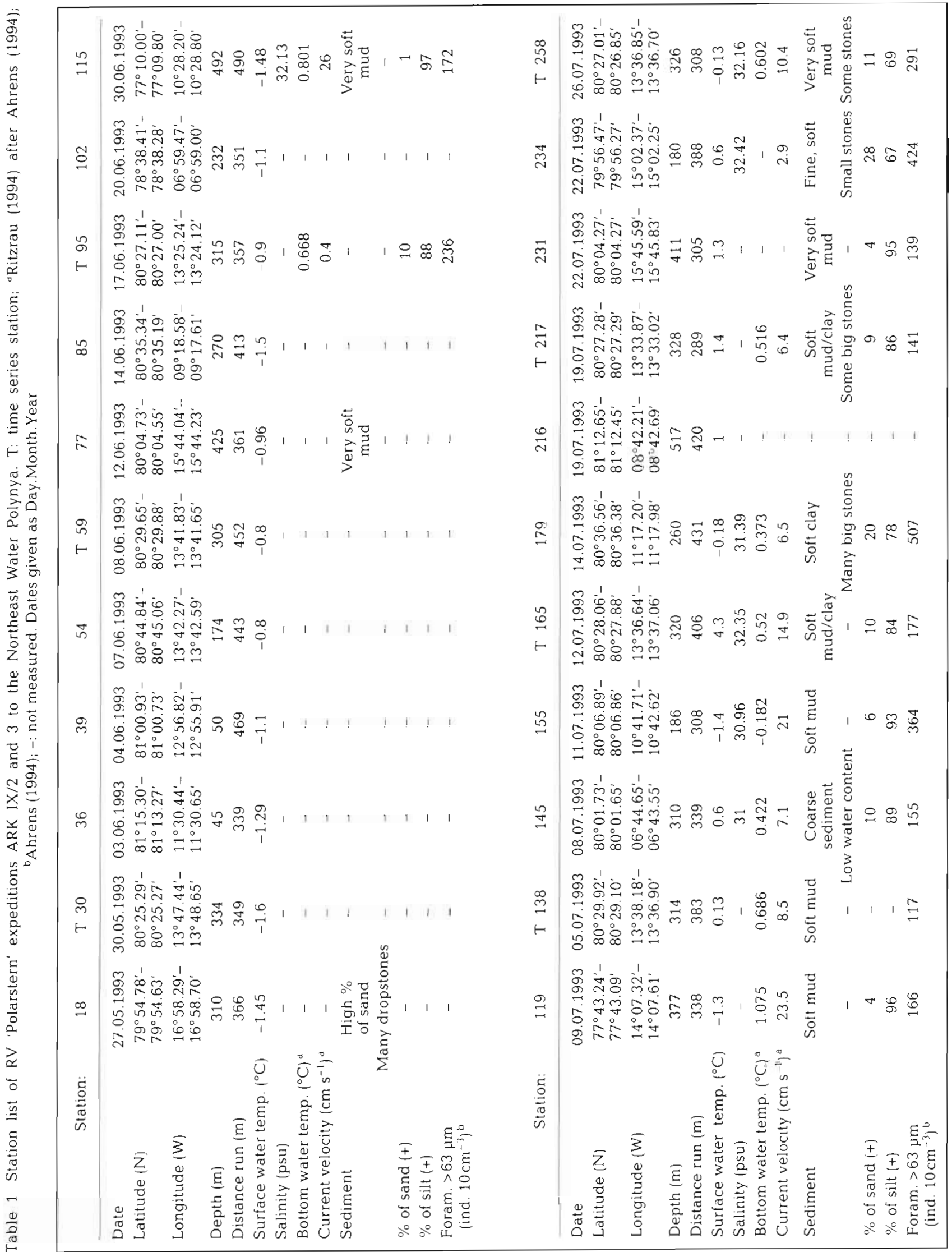


blance, both for classification and ordination. The multivariate pattern in terms of station similarities was depicted by dendrograms for cluster analysis and ordination biplots for multidimensional scaling. Based on discontinuities recognized in these graphical representations of the overall resemblance patterns distinct species assemblages were arbitrarily differentiated and marked. For the computation of similarities between any 2 clusters the Unweighted PairGroup Method using Arithmetic Averages (UPGMA) was used.

Station parameters were computed for each station from the NEW Polynya. In Table 4 the dominant species with their maximal dominance, and the real and cumulative numbers of species at stations are given and calculated diversity and evenness indices are shown. Abundance and constancy of peracarid species at the stations was parameterized by certain measures such as median and range of numbers of individuals per catch, percent dominance, and frequency of occurrence.

The term species diversity is used to mean species richness, i.e. the number of species sampled at a station (Hurlbert 1971). For comparisons of diversity patterns of the samples, the Shannon-Wiener index of diversity $\left(H^{\prime}\right)$ (Shannon \& Weaver 1949) was calculated for each station. $H^{\prime}$ is dependent on sample size. Because there were great differences in the sample sizes in this investigation, sample size was standardized; moreover, the index was supplemented by rarefaction curves (after Sanders 1968) for all stations in order to compare the expected number of species in equally large samples. Soetart \& Heip (1990) describe the dependence of the diversity indices on the sample sizes, which is more pronounced in highly diverse environments. However, there is no doubt that the sample size at the stations is large enough for this study (Table 2).

Table 3. Overview of diversity of the peracarid taxa in the NEW Polynya

\begin{tabular}{|lrrrrrr|}
\hline & Amphipoda & Cumacea & Isopoda & Mysidacea & Tanaidacea & Total \\
\hline Families & 28 & 5 & 16 & 1 & 1 & 51 \\
Genera & 68 & 10 & 31 & 6 & 6 & 121 \\
Species & 130 & 31 & 52 & 8 & 8 & 229 \\
Specimens & 31438 & 34377 & 27797 & 13389 & 3322 & 110323 \\
\hline
\end{tabular}

\section{RESULTS}

The exact number of specimens analysed was 38322 . These were 229 species belonging to 121 genera and 51 families (Table 3). In the part of the NEW Polynya sampled during our cruise 229 species of peracarid crustaceans were found (Tables $2 \& 3$ ). These species comprise a total of 110323 individuals at all stations (including the non-quantitative Stns 30 and 59) when standardized for $1000 \mathrm{~m}$ hauls (Table 2). Stns 30 and 59 were excluded in further analyses as the EBS was blocked by stones.

Among the Peracarida, Cumacea were most frequent (33.1\%), followed by Amphipoda (31.4\%), Isopoda $(21.6 \%)$, Mysidacea $(10.6 \%)$, and Tanaidacea $(3.3 \%$ ) (Tables $2 \& 3)$. Amphipoda, however, were most diverse and comprised 130 species (57\%). Isopoda were second in diversity $(22.6 \%)$, followed by Cumacea $(13.5 \%)$, and Mysidacea and Tanaidacea (3.5\% each) (Table 3). The most abundant family sampled was the Diastylidae (Cumacea), and Leptostylis villosa was the dominant peracarid species in the polynya (Table 4). Stn 179 showed the highest abundance of 
Table 4. Station parameters of the NEW Polynya, with most dominant species. Sum: sum of individuals of each station; Max. dom. $\%$ dominance of the dominant species of the station; $S$ : number of species at each station; E(S): estimated number of species calculated with the rarefaction method of Sanders (1968) for a standardized abundance; $H^{\prime}$ ' diversity index of Shannon $=$ $-\Sigma(\mathrm{n} / \mathrm{N}) \ln (\mathrm{n} / \mathrm{N})$; Pielou: evenness index of Pielou $(1966)=H^{\prime} / \ln (S)$

\begin{tabular}{|c|c|c|c|c|c|c|c|}
\hline Stn & Sum & Max. dom. & Dominant species & $S$ & $E(S)$ & $H^{\prime}$ & Pielou \\
\hline 18 & 3563 & 17.2 & Halirages fulvocinctus & 73 & 10.1 & 3.322 & 0.779 \\
\hline 36 & 4989 & 12.7 & Monoculodes sp. & 42 & 8.6 & 2.695 & 0.726 \\
\hline 39 & 7228 & 24.9 & Westwoodilla megalops & 48 & 8 & 2.613 & 0.695 \\
\hline 54 & 1808 & 25.2 & Bathymedon sp. & 53 & 8.6 & 2.854 & 0.726 \\
\hline 77 & 3143 & 38 & Eurycope brevirostris & 61 & 8 & 2.708 & 0.659 \\
\hline 85 & 4693 & 24.5 & Erythrops erythrophthalma & 66 & 8.5 & 2.834 & 0.689 \\
\hline 95 & 9410 & 16.4 & Eurycope brevirostris & 82 & 9.7 & 3.221 & 0.737 \\
\hline 102 & 5420 & 15.8 & Brachydiastylis nimia & 90 & 9.9 & 3.279 & 0.734 \\
\hline 115 & 532 & 19.1 & Gnathia stygia & 44 & 9.2 & 2.976 & 0.796 \\
\hline 119 & 798 & 21.1 & Erythrops glacialis & 40 & 8.7 & 2.84 & 0.775 \\
\hline 138 & 6248 & 19.7 & Leptostylis villosa & 79 & 9.6 & 3.216 & 0.745 \\
\hline 145 & 4085 & 16.1 & Eurycope brevirostris & 75 & 9.6 & 3.143 & 0.733 \\
\hline 155 & 1.2040 & 13.5 & Leucon nasica & 85 & 9.4 & 3.118 & 0.711 \\
\hline 165 & 9610 & 13.9 & Leptostylis villosa & 79 & 9.5 & 3.124 & 0.719 \\
\hline 179 & 15929 & 14.7 & Bathymedonsp. & 82 & 10.1 & 3.281 & 0.747 \\
\hline 216 & 312 & 12.1 & Pseudomma frigidum & 35 & 9.9 & 3.089 & 0.876 \\
\hline 217 & 5937 & 15.7 & Pseudomma frigidum & 64 & 9.9 & 3.199 & 0.775 \\
\hline 231 & 5022 & 13.4 & Eurycope inermis & 73 & 10.6 & 3.447 & 0.809 \\
\hline 234 & 3929 & 22.1 & Exythrops erythrophthalma & 73 & 9.5 & 3.138 & 0.734 \\
\hline 258 & 5518 & 14.5 & Eurycope inermis & 84 & 10 & 3.324 & 0.754 \\
\hline Total & $110214^{\mathrm{d}}$ & 7.5 & Leptostylis villosa & 229 & 11.7 & 4.037 & 0.744 \\
\hline
\end{tabular}

Peracarida (Fig 2a). Total diversity was highest at Stns 102, 155, and 258 (Fig. 2b) but was also quite high at some other stations. The abundance of cumaceans and isopods was higher than that of amphipods at many stations in the NEW Polynya (Table 2); however, at Stn 39 amphipods were predominant. In terms of relative diversity, amphipods were most diverse at 18 stations, and only at Stns 115 and 216 (deep stations) were the Isopoda more diverse (Table 2).

The northernmost station (216) was also the deepest $(517 \mathrm{~m})$ and showed the lowest abundance and diversity of peracarid taxa. Stns 115 and 119 were the southernmost stations and were still relatively deep (377 to $492 \mathrm{~m}$ ). The abundance and diversity values at these 2 stations were both low, suggesting that depth may be a controlling factor. However, Fig. 3 shows that there was no correlation of abundance or diversity with depth and, therefore, factors other than depth must be involved. Although there are no significant relationships between depth and diversity, some taxa do show patterns (A. Brandt, S. Vassilenko, D. Piepenburg \& M. Thurston unpubl.). Amphipod numbers and diversity (based on proportional representation in samples) are significantly higher (Spearman's rank correlation coefficient) at shallow depths, whereas the reverse is true for isopods and mysids.
Both abundance and diversity were highest at stations sampled around $300 \mathrm{~m}$ depth, especially in the Westwind Trough in the north of the polynya (Fig. 2b). Fig. $4 \mathrm{a}, \mathrm{b}$ shows the dendrogram of a cluster analysis of the stations on the basis of the peracarid distribution. Stn 54 does not fit very well with Stns 115, 119 and 216 and has a more random position as illustrated in the MDS plot (Fig. 4b). Stns 115, 119 and 216 are the deepest stations and also show the lowest abundance values, which is most probably correlated with the low availability of nutrients and the low productivity of the water masses due to both ice cover and hydrography (e.g. circulation pattern). Although Stn 234 is similar in species composition to 179 and 155 (Fig. 4a, b), it is located much further away and the species assemblages there must be influenced by other forces than at Stns 179 and 155.

Stn 102 was situated on the eastern Belgica Bank (Fig 1), between the stations of the Belgica Dyb and the Norske and Westwind Troughs, where most stations were located. This station showed abundance values between those of the southern stations (115 and 119, very low abundances) and, for example, those of the time series stations of Stns 179 and 155, which showed extremely high values. Abundance values were highest for Stn 179, which might be due 
to the current direction and the accumulation of organic matter resulting from lateral advection, which is similar, but a little less pronounced, at Stn 155. Stn 145 was located at the northeastern edge of AWI Bank (ca $80^{\circ} \mathrm{N}, 08^{\circ} \mathrm{W}$ ), close to the influence of the cold Arctic water; this station also shows low abundance values. Stns 36 and 39 were shallowest (about $50 \mathrm{~m}$ ), situated close to the fast-ice margin off Kronprins Christians Land. Here, sediments contained a higher percentage of sand than at the other stations, as seen on the surfaces of box corers from the same locality (Ahrens 1994). The amphipod abundance of these stations is somewhat higher than at the time series stations; however, the total peracarid abundance is much lower than at Stns 179 and 155. Stns 18 and 234 were situated in the East Greenland Coastal Current, close to the southern area of fast-ice, which covers part of the Norske Trough. This water probably transports relatively low amounts of nutrients in this area, as it flows mainly under the ice. These 2 stations and Stns 77 and 231. which are nearby, showed low abundance. Interestingly, Stn 85 also had a relatively low abundance despite its proximity to Stn 179, where the highest level of abundance was recorded. The time series stations and Stns 54, 179 and 85 lie in the outflow from the northern Ingolfsfjord, which is significant in terms of community patterns (Brandt et al. unpubl.) The more southern Dijmpha Sund may have some influence on Stns 18,77 , and 231

\section{DISCUSSION}

In contrast to megafaunal organisms, macrobenthic peracarid crustaceans are too small for in situ analysis by camera or video systems (e.g. Hargrave 1985, Smith 1985, Piepenburg 1988, Hecker 1990, Gutt 1991, Piepenburg \& von Juterzenka 1994), and are rarely abundant enough to be sampled adequately by quantitative samplers, such as box corers. Traditionally box cores cover areas of $0.25 \mathrm{~m}^{2}$. Such samples cannot provide unbiased abundance estimates for species which might occur in low densities (e.g. Tanaidacea), swarms (Mysidacea), or have a patchy distribution due to food availability (all Peracarida) (Holme \& McIntyre 1984).
Total Abundance

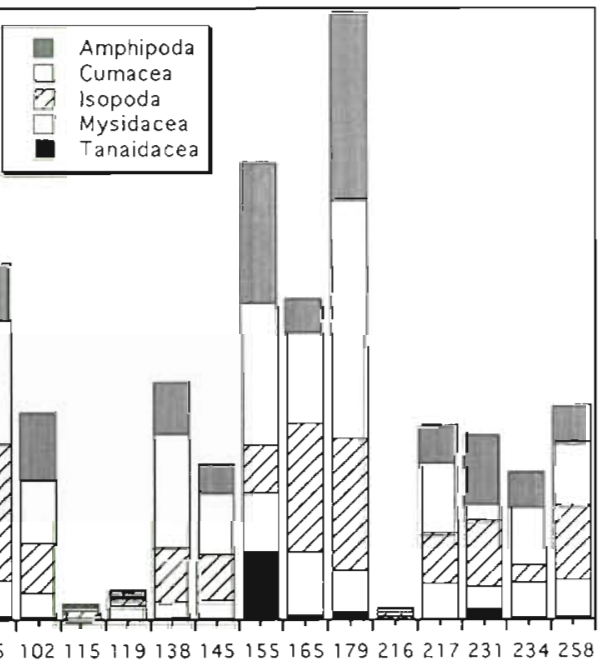

Total Diversity

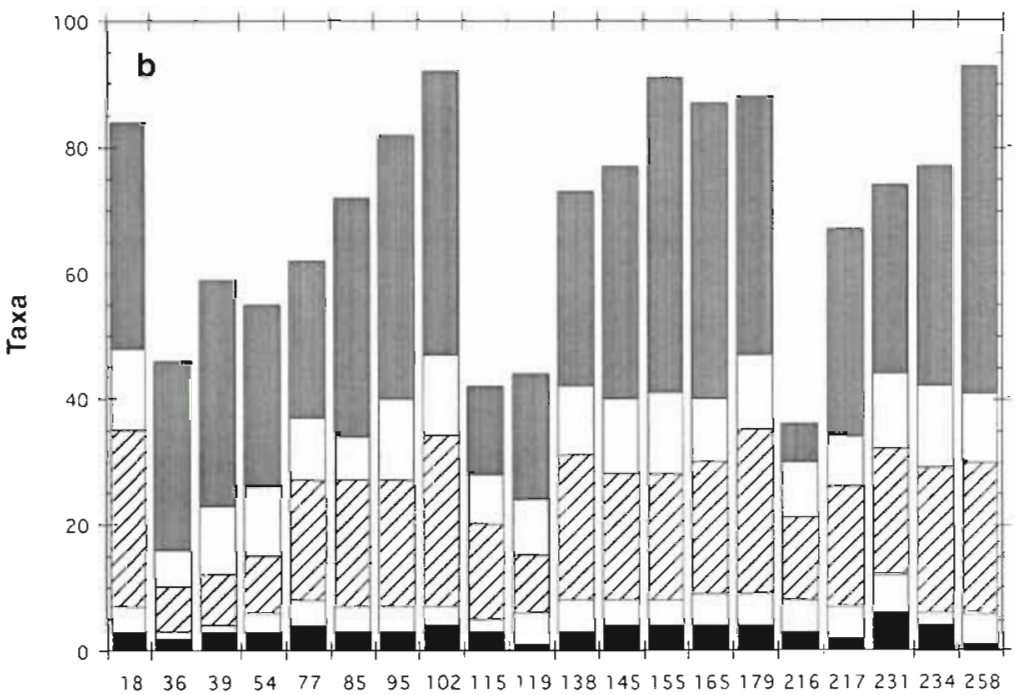

Stations

Fig. 2. (a) Total abundance and (b) total diversity of all peracarid taxa at 20 stations in the Northeast Water Polynya

'Winnowing' by the box may also influence the sample efficiency to an unknown degree. The best method for catching greater amounts of these taxa is the use of towed gear, such as the epibenthic sledge (modified after Rothlishberg \& Pearcy 1977), despite potential avoidance reactions by the more mobile organisms such as mysids or some amphipods. Towed gear has been frequently used in the past to catch peracarids even though, depending on the smoothness of the ground, it may not always work with exactly the same efficiency (e.g. Buhl-Jensen 1986, Svavarsson et al. 1990, 1993, Brattegard \& Fosså 1991). Nevertheless, the EBS is still the best instrument to sample small peracarids. Replicates using this gear at the same stations 
a

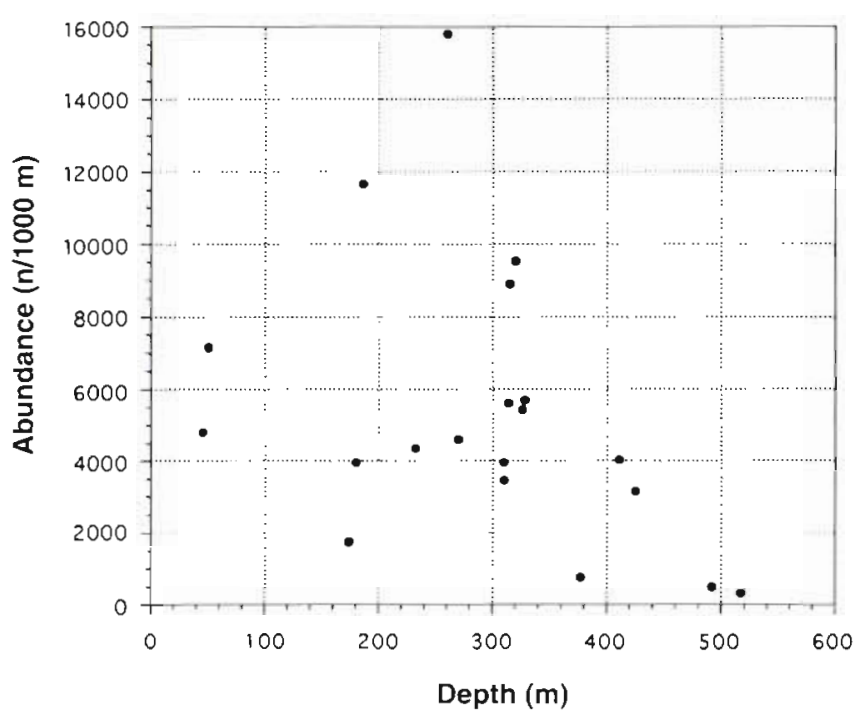

b

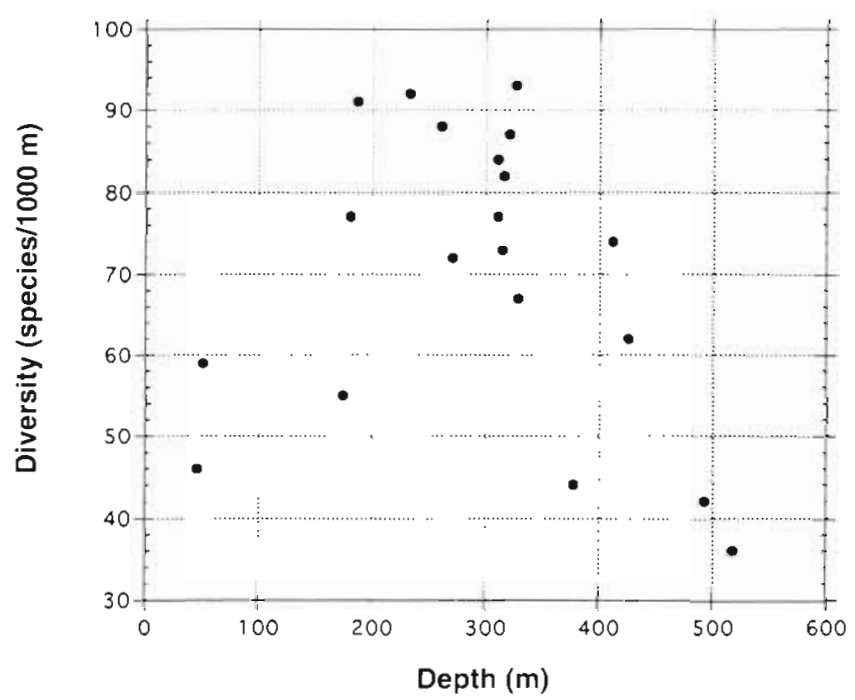

Fig. 3. Relation between (a) depth and abundance and between (b) depth and diversity at 20 stations sampled in the polynya (for exact depth of stations see Table 1)

proved to be as variable as those among different stations; therefore Brattegard \& Fosså (1991) suggest taking only 1 sample at each station. In the NEW Polynya, the sledge is usually towed at $1 \mathrm{knot}$, and mysids and amphipods are caught in considerable numbers (Tables 2 \& 3).

The high biodiversity in the NEW Polynya described for Peracarida (229 species) implies that the environmental conditions (e.g time of opening and closing of the polynya) must have been reJatively stable over a long period of time northeast of Greenland. Intense melting of ice and subsequent changes in seawater salinity might strongly disturb the benthic community (not only of peracarid crustaceans) in this area and, hence, affect the biological balance of this ecotope.

The cluster analysis of the stations (Fig. 4) revealed that, generally, stations which lay very close together (it was attempted to take the samples at exactly the same locality; Ahrens 1994, p. 69) also showed the highest resemblance (time series stations 95, 138, 165, 217, and 258), which might indicate that seasonal variability (samples taken over a period of more than $2 \mathrm{mo}$ ) is not as important as geographical position of the stations. Stns 179 and 155 in the Westwind Trough were very similar to the time series stations with regard to species composition, but abundance values were higher.

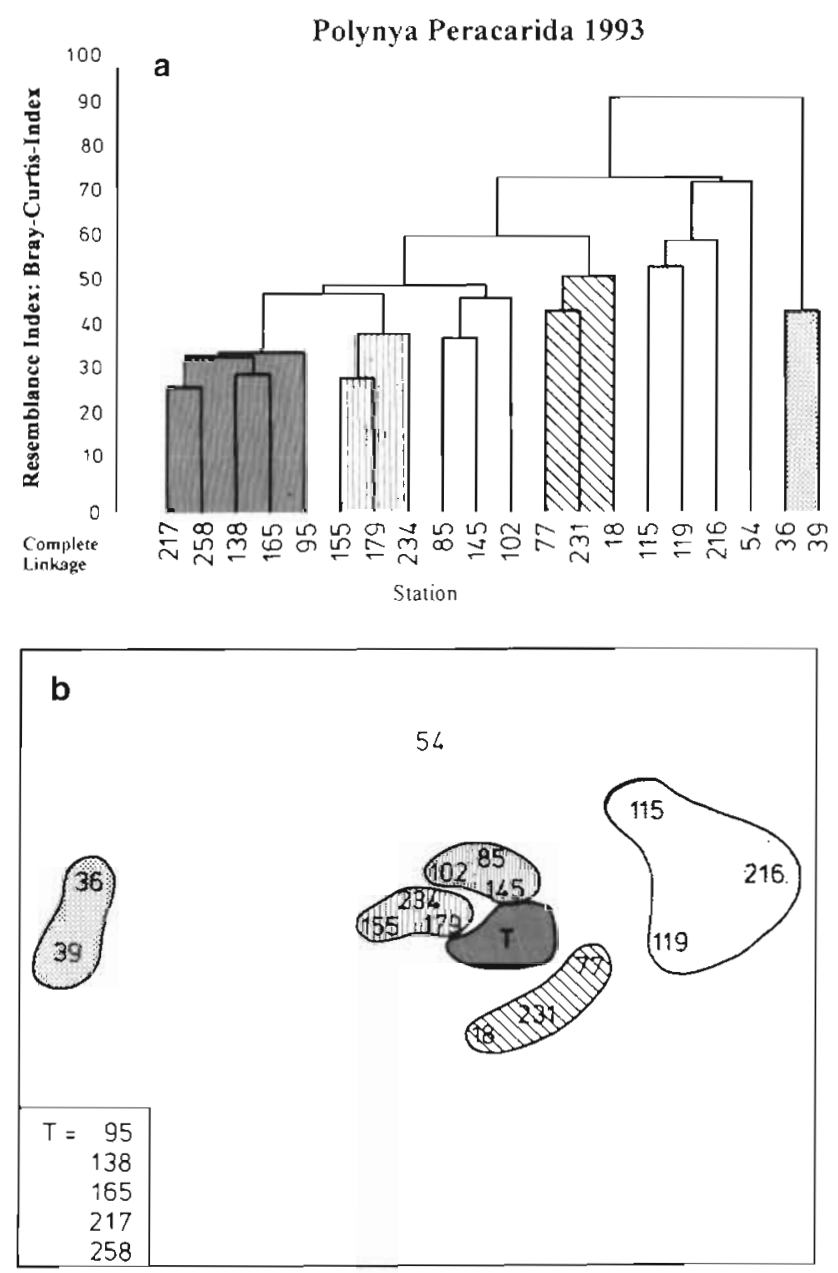

Fig. 4. (a) Dendrogram from the cluster analysis and (b) plot of the multidimensional scaling ( 2 dimensions) of the EBS samples taken in the Northeast Water Polynya from May to August 1993 (fourth root transformation of species abundance values; Bray Curtis Index as resemblance measure; complete linkage strategy, cophenetic index 0.9389); stress of MDS solution 0.092 
Very few publications on faunal composition of peracarid taxa contain data comparable with the polynya data reported here. Buhl-Jensen (1986), also employing the same construction of an EBS, registered 159 amphipod species from the Norwegian continental shelf $\left(60\right.$ to $\left.67^{\circ} \mathrm{N}\right)$. In the NEW Polynya, which is much further north and affected predominantly by cold Arctic polar water of the East Greenland Current, 130 amphipod species were sampled. Svavarsson et al. (1993b; compare also Svavarsson et al. 1990) listed 106 Arctic and Arctic-boreal species of asellote isopods (these are among the most predominant animals of the deep sea and polar fauna) in the Norwegian, Greenland, Iceland, and North Polar Seas. Only 69 of these listed species had been reported from the depth range 0 to $517 \mathrm{~m}$ (Stn 216, the deepest station sampled in the polynya). In the NEW Polynya 42 of the 69 species have been recorded in our study. This represents twothirds of all known Arctic-boreal and Arctic asellote isopods, suggesting that the EBS has a high catch efficiency and the fauna of the NEW Polynya are highly diverse. The number of asellotes found in the polynya is extraordinarily high if one takes into consideration that these findings refer to 22 stations, while those of Svavarsson et al. (1993b), who also referred to EBS samples in their recent investigations, and literature data have accumulated over the past $100 \mathrm{yr}$. On a smaller scale, differences between the northern and southern area of the NEW Polynya are pronounced especially with regard to abundance of peracarid taxa as well as between banks and troughs in general. Generally the banks are dominated by coarse sediments with many smaller stones or rocks which are inhabited by sessile suspension feeders, sponges, alcyonarians and soft corals. In general the larger megabenthic animals, ophiuroids, starfishes, pycnogonids, bivalves, etc. dominate at these stations. However, the slopes of the banks and the bottoms of the troughs are characterized by soft sediments, with a lower number of megabenthic animals. At these stations the importance of smaller macrobenthic taxa, especially peracarid crustaceans and polychaetes $(\mathrm{K}$. Schnack pers. comm. K. Schnack \& A. Brandt unpubl. data from box corer analyses taken at the same stations), increased. These differences can be due to either different current regimes (stronger or weaker current velocities, direction, etc.) (Künitzer et al. 1991), or different sedimentation patterns (Grebmeier et al. 1988, 1989, Basford et al. 1990, Jensen et al. 1992), sediment erosion by hydrodynamic forces, or other abiotic parameters, such as temperature and salinity (Dyer et al. 1983). Similar to the present results for the peracarid abundance in the NEW Polynya, Ambrose \& Renaud (1995, their Fig. 3) found much higher densities of polychaetes in the troughs, especially in the north and northeast of the NEW Polynya, compared to the Southern Trough They attributed this to grazing of herbivorous copepods, which is about 3 times higher in the south (Ashjian et al. 1995). Ambrose \& Renaud (1995) found no relationship between water-column and benthic pigment concentration (the most important predictor of infaunal density and polychaete biomass) in the Southern Trough, although phytoplankton standing crops were similar to those in the Northern Trough (Smith et al. 1995). In their opinion this might indicate that water column and benthos were decoupled in the south, possibly due to the abundance of grazing phytoplankton. Pomeroy (1974) and Jumars et al. (1989) suggested that grazers are needed to stimulate bacterial activity (by providing substrate of high quality); the grazers should enhance the role and importance of the microbial loop in processing carbon. This hypothesis, however, does not prove true for the NEW Polynya, because in the Northern Trough heterotrophic activity of bacteria in the BNL was generally higher than in the Southern Trough (Belgica Dyb) (Ritzrau 1994, p. 96-99). On the other hand the lower numbers of phytoplankton in the Northern Trough might reduce carbon cycling in the water column and result in a more efficient transfer of carbon from the pelagial to the benthos.

The diversity of Peracarida in the polynya area turned out to be much higher than had been expected, especially if we consider recent discussions on decrease of diversity with latitude (e.g. May 1992 Gage \& May 1993, Poore \& Wilson 1993, Rex et al. 1993, Brey et al. 1994). However, such arguments are based on surveys deeper than $500 \mathrm{~m}$, whereas stations in the NEW Polynya were situated on the continental shelf - some were almost $500 \mathrm{~m}$ deep, the deepest (Stn 216) was $517 \mathrm{~m}$. Nevertheless, no obvious correlation of abundance or diversity with depth could be found (Fig. 3a, b). At our stations diversity was highest around $300 \mathrm{~m}$ depth (Fig. 3b). Isopoda were more diverse than Amphipoda in the deeper stations (115 and 216), which might indicate an increasing importance of Isopoda within the peracarid community with depth (Table 2). Brey et al. (1994) cautioned against general statements, such as a decrease of deep-sea diversity with latitude. Our findings in the NEW Polynya also suggest that, rather than over-emphasizing a single parameter (such as latitude) and neglecting the others a variety of different biotic and abiotic parameters must be considered to explain species communities. Moreover, studies of biodiversity at high latitudes have been performed infrequently until now, and investigations in the Antarctic have already falsified the hypotheses of Rex et al. (1993) (Brey et al. 1994).

General discussions on diversity (e.g. Sanders et al. 1965) also have to be considered, as lateral advection and plankton and ice-algae blooms might not be the 
only effects influencing peracarid community composition. The polynya area is open for only 4 to 5 mo per year, and, hence, is far from being uniform. However, biological disturbance processes (Dayton \& Hessler 1972, Smith \& Hamilton 1988), competition (Grassle \& Sanders 1973), habitat heterogeneity (Jumars 1976), and competition and predation correlated with production (Rex 1976), or small-scale disturbance within stable communities (Grassle \& Morse-Porteous 1987) might be biological factors which could well influence the communities characterized for the different stations. These biological inter-species relationships and effects might be more important during the winter months, when little or no organic matter reaches the seafloor or remains from summer deposition.

Peracarids, such as epifaunal isopods, which can burrow in the first centimeter of the sediment (e.g. Ischnomesidae, Eurycopidae, Ilyarachnidae, Desmosomatidae) (Hessler \& Strömberg 1989) and are mainly deposit feeders, have an important influence on niche diversification, bioturbation effects, and benthic carbon cycling (Brandt 1993, Brandt \& Piepenburg 1994). As peracarid crustaceans are known to increase in importance with depth (Dahl et al. 1976, Grassle \& Maciolek 1992), it might be expected that a vertical transect of the East Greenland shelf would reveal highly diverse peracarid communities, even at deeper stations. This question will be answered in future papers (author's unpubl. data from expedition ARK X1 with RV 'Polarstern' at $75^{\circ} \mathrm{N}$, July-August 1994).

The surface and bottom water temperature was slightly lower at the southern stations (115 and 119) compared with the stations of the Norske and Westwind Troughs (Ritzrau 1994, p. 96; compare Ahrens 1994, p. 108). However, these slight temperature differences most probably do not explain the higher abundance in the north since temperature changes within a range of \pm 1 to $2^{\circ} \mathrm{C}$ do not affect the life of these taxa, as was observed in peracarids (e.g. Anonyx nugax, Paramphitoe hystrix) kept alive in aquaria for some time. Neither were differences in salinity pronounced between the stations (compare Machoczek 1989): the presence of peracarids thus cannot be affected by this parameter either. In aquaria the animals were able to tolerate changes in salinity of 2 to $3 \%$ (A. Brandt unpubl.). The differences in the sediment surfaces on banks and in troughs can probably be attributed to higher current velocities on the banks in comparison to the troughs. This could explain differences in abundance of peracarids between bank and trough stations (the amount of fine organic matter available for feeding of peracarids might be lower in areas of higher current velocities); however, it does not explain differences between southern and northern trough stations. Investigations of chlorophyll a and
ATP contents of the upper sediment layer do not explain these differences (A.hrens 1994, p. 53, 108; Graf \& Scheltz pers. comm.). Only at Stn 179 in the north did the highest values for the incorporation of chlorophyll into the sediment and for biological activity (ATP measurements; for methods see Graf \& Linke 1992. Heip et al. 1992) correspond with the highest abundance values of Peracarida. The differences found for peracarids between northern and southern troughs of the polynya area resemble meiobenthic community patterns, as the Southern Trough (Belgica Dyb) is characterized by a distinct nematode community (R. Herman \& P Jensen pers. comm.). The high values in peracarid abundance and in chlorophyll incorporation into the sediment found at Stn 179 might indicate the impact of epibenthic peracarids on bioturbation processes in this area (Grebmeier \& McRoy 1989, Brandt 1993, Brandt \& Piepenburg 1994). The incongruence in our findings concerning the lower abundance of peracarids in the south, where the chlorophyll incorporation and biological activity (ATP measurements) are not strikingly lower, might indicate a greater abundance of smaller meiobenthic organisms in the south, which could lead to a most rapid incorporation of organic matter into the sediment by bioturbation processes. On the other hand, Ambrose \& Renard (1995) implicate a possible grazing effect of copepods for the lower densities of polychaetes in the southern trough (Ashjian et al. 1995, Smith et al. 1995). Grazing would also affect the availability of food for peracarids.

Peracarid crustaceans and other epi- and suprabenthic animals depend on organic material, which is accumulated in the near bottom water (BNL). Thus the content of organic matter (e.g. particulate organic carbon, POC) in the BNL must have a strong impact on the peracarid communities. Therefore it is not surprising that we found the highest values of peracarid abundance at stations where POC values in the BNL were highest (compare Ritzrau 1994, p. 96-99). At the southern stations (115 and 119) the POC content was not low; however, higher amounts of freshly sedimented organic material (especially chllorophyll equivalents) in the BNL were found in the Northern Trough, especially at the time series stations, and at Stn 179 we found the highest values (Ritzrau 1994).

\section{CONCLUSIONS}

These findings suggest the following interpretation: the water masses from the Arctic Ocean flowing south through the Fram Strait carry only a relatively low amount of nutrients, primary production being not yet possible because of the almost permanent ice cover. Water masses forming the East Greenland Current 
flow south along the eastern side of Belgica and $\mathrm{Ob}$ Bank where the ice extent is still pronounced, especially in May, but also in June. Driven by the topography of the Belgica Dyb and the north-flowing coastal current off Greenland, these water masses deviate towards the mainland and form the anticyclonal gyre around Belgica Bank. Here, in the opening of the Belgica Dyb, the ice cover is almost permanent, Stns 115 and 119 (close to the Greenland continental slope) are situated in an area of almost constant ice cover, and only slight movements of the ice occur (Ritzrau 1994, p. 38, T. König pers. comm.). Primary production is hardly possible; and, due to lateral advection, blooms of algae at the ice edges probably do not affect the benthic communities.

In the northern part of the NEW Polynya, however, we find the highest values of POC (in terms of freshly sedimented material, chlorophyll equivalents) and peracarid abundance, probably resulting from a combination of hydrographic condition and primary and especially ice-edge production. The northern part of the polynya is broadest and open longest. Movement of the ice flows is very high in the north (König pers. comm.), which accelerates blooms of ice algae at the floes' margins. The effect of production in the water column is probably of minor importance, relative to the ice-algae blooms. If we assume a higher productivity in the northeast of the polynya and consider the northward movement of the East Greenland Coastal Current, it becomes obvious that the finding of the higher POC values can be explained by high sedimentation of organic matter (ice algae) and by lateral advection (accumulation of organic matter in the north). Assumption of these processes also implies that peracarid abundance should be lower at stations close to the ice edge $(18,234,77,231)$ (compare also schematic model of Ritzrau 1994, p. 60), and nearer the northern fast-ice extension $(36,39)$. Except for the Amphipoda at Stns 36 and 39 , this did prove true (Table 2). The process of lateral advection might also explain the slightly higher values at Stn 179 compared with those at Stn 155, which also lies in the area of relatively low ice cover but on the southern slope of the Westwind Trough where the influence of the lateral advection might be slightly reduced.

The high biodiversity of Peracarida in the NEW Polynya, and also the presence of many juveniles and ovigerous females (Brandt et al. unpubl.) indicates high productivity of this area during summer months Both abundance and biodiversity of peracarid communities in the NEW Polynya are influenced mainly by productivity (particularly ice algae) (Ritzrau 1994, Ambrose \& Renaud 1995, Ashjian et al. 1995, Smith et al. 1995) and hydrography (lateral advection) (Ritzrau 1994, Schneider \& Budéus 1994) during summer months. In winter, when the polynya is closed, biological processes of interspecies relationships (such as competition and predation) likely control the composition of peracarids. The high abundance of peracarid crustaceans at Stn 179, where we also found a high concentration of chlorophyll equivalents (POC) in the BNL (Ritzrau 1994), chlorophyll incorporation into the sediment and biological activity (ATP content) of the upper sediment layer (Graf \& Scheltz pers. comm.), could indicate that they have a high potential for bioturbation and resuspension and, hence, are important in benthic carbon cycling.

Acknowledgements. The author is grateful to the German Science Foundation for supporting the SFB 313 and to the crew of RV 'Polarstern' for their help and logistic support during the expedition ARK IX/2-3. I am especially grateful to Dr $D$. Piepenburg for providing the EBS samples during the first leg, ARK IX/2. Thanks are due especially to Dr S. Vassilenko for help with the identification of amphipoda and cumaceans For help with taxonomic problems I owe thanks to Dr O. Coleman, Dr A. Golikov, Prof. Dr O. G. Kussakin, Prof. Dr W Vader. M. Ahrens, Dr W. Ambrose, Prof. Dr G. Graf, Dr R. Herman, Dr D. Piepenburg, Dr W Ritzrau, and A. Scheltz stimulated discussion with the help of their unpublished data. Furthermore l owe thanks to Dr W. Ambrose, Dr D. Barthel, Dr M. Thurston, and Dr M. White, who read and commented on an early version of the manuscript, as well as 2 anonymous reviewers. This is publication no. 234 of Sonderforschungsbereich 313 of the University of Kiel.

\section{LITERATURE CITED}

Ahrens M (1994) Benthische Foraminiferen in der Northeastwater-Polynya, Europäisches Nordmeer. Diplomarbeit, Universität Kiel

Ambrose WG, Renaud PE (1995) Benthic response to water column productivity patterns: evidence for benthicpelagic coupling in the Northeast Water Polynya. J geophys Res 100:4411-4421

Ashjian K, Smith S, Lane P (1994) The Northeast Water Polynya during summer 1992: secondary production and the distribution of crustacean zooplankton. J geophys Res 100:4371-4388

Barthel D (1992) Do hexactinellids structure Antarctic sponge associations? Ophelia 36:111-118

Basford DJ, Eleftheriou A, Raffaelli D (1989) The epifauna of the northern North Sea $\left(56^{\circ}-61^{\circ} \mathrm{N}\right)$. J mar biol Ass UK 69 $387-407$

Billett, DSM, Lampitt RS, Rice AL, Mantoura RFC (1983) Seasonal sedimentation of phytoplankton to the deep-sea benthos. Nature 302:520-522

Birgisdottir L (1990) Die paläo-ozeanographische Entwicklung der Islandsee in den letzten 550000 Jahren. Ber Sonderforschungsbereich 313 (34):1-112

Bourke RH, Newton JL, Paquette PG, Tunicliffe MD (1987) Circulation and water masses of the East Greenland Shelf J geophys Res 92 (C7):6729-6740

Brandt A (1993) Composition, abundance, and diversity of peracarid crustaceans on a transect of the Kolbeinsey Ridge, north of Iceland. Polar Biol 13:565-576 
Brandt A, Piepenburg D (1994) Peracarid crustacean assemblages of the Kolbemsey Rudge, north of Iceland. Polar Biol $14: 97-105$

Brattegard T, Fosså JH (1991) Replicability of an epibenthic sampler. J mar biol Ass UK 71:153-166

Bray JR, Curtis JT (1957) An ordination of the upland forest of Southern Wisconsin. Ecol Monogr 27:225-349

Brey T, Klages $M$, Dahm $C$, Gorny $M$, Gutt J, Hain S, Stiller M, Arntz WE, Wägele JW, Zimmermann A (1994) Antarctic benthic diversity. Nature 368:297

Budéus G, Maul AA, Krause G (1993) Variabihty in the Greenland Sea as revealed by a repeated high spatial resolution CTD survey. J geophys Res 98:9985-10000

Buhl-Jensen L (1986) The benthic amphipod fauna of the Wost-Norwegian continental shelf compared with the fauna of five adjacent fjords. Sarsia 7 1:193-208

Carey AG (1991) Ecology of the North American Arctic continental shelf benthos: a review. Cont Shelf Res 11(8-10): $865-883$

Dahl EL, Laubier M, Sibuet M, Strömberg JO (1976) Some quantitative results on benthic communities of the deep Norwegian Sea. Astarte 5:61-79

Dayton PK, Hessler RR (1972) Role of biological disturbance in maintaining diversity in the deep sea. Deep Sea Res 19: $199-208$

Deming J (1993) Northeast Water Polynya: Polar Sea cruise results. EOS Trans Am Geophys Un 74(16):185, 195-196

Dyer MF, Fry WG, Fry PD, Cranmer GJ (1983) Benthic regions within the North Sea. J mar brol. Ass UK 63 $683-693$

Field JG,Clarke KR, Warwick RM (1982) A practical strategy for analyzing mutispecies distribution patterns. Mar Ecol Prog Ser 8:37-52

Gage JD, May RM (1993) A dip into the deep seas. Nature 365:609-610

Gage JD, Tyler PA (1991) Deep-sea biology: a natural history of organisms at the deep-sea floor. Cambridge University Press, Cambridge

Graf G (1989) Benthic-pelagic coupling in a deep-sea benthic community. Nature 341:437-4.39

Graf G (1992) Benthic-pelagic coupling: a benthic view. Oceanogr mar Biol A Rev 30:149-190

Graf G, Linke P (1992) Adenosine nucleotides as indicator of deep-sea benthic metabolism. In: Rowe GT (ed) Deep-sea food chains and global carbon cycle. NATO ASI Series, Kluwer, Dordrecht, p 237-243

Grassle JF, Maciolek NJ (1992) Deep-sea species richness: regional and local diversity estimates from quantitative bottom samples. Am Nat 139:313-341

Grassle JF, Morse-Porteous LS (1987) Macrofaunal colonization of disturbed deep-sea environments and the structure of deep-sea communities. Deep Sea Res 34:1911-1950

Grassle JF, Sanders HL (1973) Life histories and the role of disturbance. Deep Sea Res 20:643-659

Grebmeier JM, McRoy CP, Feder HM (1988) Pelagic-benthic coupling on the shelf of the northern Bering and Chukchi Seas. 1. Food supply source and benthic biomass. Mar Ecol Prog Ser 48:57-67

Grebmeier JM, Feder HM, McRoy CP (1989) Pelagic-benthic coupling on the shelf of the northern Bering and Chukchi Seas. II. Benthic community structure. Mar Ecol Prog Ser $51: 253-268$

Grebmeier JM, McRoy CP (1989) Pelagic-benthic coupling on the shelf of the northern Bering and Chukchi Seas. III. Benthic food supply and carbon cycling. Mar Ecol Prog Ser 53:79-91

Gutt $J$ (1991) On the distribution and ecology of holothurians in the Weddell Sea (Antarctica). Polar Biol 11:145-155

Hargrave BT (1985) Feeding rates of abyssal scavenging amphipods (Eurythenes gryllus) determined in situ by time-lapse photography. Deep Sea Res 32:443-450

Hebbeln D, Wefer G (1991) Effects of ice coverage and icerafted material on sedimentation in the Fram Strait. Nature 350(6317):409-411

Hecker B (1990) Photographic evidence for the rapid flux of particles to the sea floor and their transport down the continental slope. Deep Sea Res 37:1773-1782

Heip C, Basford D, Craeymeersch JA, Dewarumez JM, Dörjes J, DeWilde P, Duineveld G, Eleftheriou A, Hermann RMJ, Niermann U, Kingston $P$, Künitzer A, Rachor E, Rumohr H, Soetart K, Soltwedel T (1992) Trends in biomass, density, and diversity of North Sea macrofauna. ICES $J$ mar Sci 49:13-22

Hempel G (1985) On the biology of polar seas, particularly the Southern Ocean In: Gray JS, Christiansen ME (eds) Marine biology of polar regions and the effects of stress on marine organisms. John Wiley \& Son, Chichester, p 3-34

Hessler RR, Strömberg JO (1989) Behaviour of Janiroidean isopods (Asellota), with special reference to deep-sea genera. Sarsia 74:145-159

Hirche HJ, Baumann M, Kattner G, Gradinger R (1991) Plankton distribution and the impact of copepod grazing on primary production in Fram Strait, Greenland Sea. J mar Syst $2: 477-486$

Hirche HJ, Bohrer RN (1987) Reproduction of the Arctic copepod Calanus glacialis in Fram Strait. Mar Biol 94:11-17

Hirche HJ, Kattner G (eds) (1994) The 1993 Northeast Water Expedition scientific cruise report of RV 'Polarstern' Arctic cruises ARK IX/2 and 3, USCG 'Polar Sea' cruise NEWP and the NEWLand expedition. Ber Polarforsch 142:1-190

Holme NA, McIntyre AD (1984) Methods for study of the marine benthos. Blackwell Scientific Publications, Oxford

Hopkins C (1991) The GIN sea - a synthesis of its physical oceanography and literature review 1972-1985. Earth-Sci Rev 30:175-318

Hurlbert SH (1971) The nonconcept of species diversity: a critique and alternative parameters. Ecology 52(4): $577-586$

Jensen P, Romohr J, Graf G (1992) Sedimetological and biological differences across a deep-sea ridge exposed to advection and accumulation of fine-grained particles. Oceanologica Acta 15(3):287-296

Jumars PA (1976) Deep-sea species diversity: does it have a characteristic scale? J mar Res 34:217-246

Jumars PA, Penry DL, Baross JA, Perry MJ, Frost BW 11989 \} Closing the microbial loop: dissolved carbon pathway to heterotrophic bacteria from incomplete ingestion. digestion, and absorption in animals. Deep Sea Res 36 $483-495$

Koch L (1945) The east Greenland ice. Meddr Grönland 130(3): $1-373$

Kruskal JB, Wish M (1978) Multidimensional scaling. Sage, London

Künitzer A, Basford D, Craeymeersch JA, Dewarumez JM, Dörjes J, Duineveld GCA, Eleftheriou A, Heip C. Herman P, Kingston P, Niermann U, Rachor H, DeWilde PAJ (1991) The benthic infauna of the North Sea: species distribution and assemblages. ICES J mar Sci 49:127-143

Machoczek D (1989) Untersuchungen historischer hydrographischer Daten des Europäischen Nordmeeres im Hinblick auf moderne Vorstellungen zur Wassermassenbildung und Zirkulation. DHI, Wiss Tech Ber 1-77

May RM (1992) Bottoms up for the oceans. Nature 357 $278-279$ 
Parkinson CL, Comiso JC, Zwally HJ, Cavalieri DJ, Gloersen P. Campbell WJ (1987) Arctic sea ice, 1973-1976: satellite passive-microwave observations. NASA, Washington, DC, Sp-489:1-296

Pielou EC (1966) The measurement of species diversity in different types of biological collections. J theor Biol 13: $131-144$

Piepenburg D (1988) Zur Zusammensetzung der Bodenfauna in der westlichen Fram-Straße. Ber Polarforsch 52:1-118

Piepenburg D, Piatkowski U (1992) A program for computeraided analyses of ecological field data. CABIOS 8(6): $587-590$

Piepenburg D, von Juterzenka K (1994) Abundance, biomass, and spatial distribution pattern of brittle stars (Echinodermata: Ophiuroidea) on the Kolbeinsey Ridge north of Iceland. Polar Biol 14:185-194

Pomeroy LR (1974) The ocean's food web, a changing paradigm. Biosci 24:499-503

Poore GCB, Wilson GDF (1993) Marine species richness. Nature 361:597-598

Rex MA (1976) Community structure in the deep-sea benthos. Ann Rev Ecol Syst 12:331-353

Rex MA, Stuart CT, Hessler RR, Allen JA, Sanders HL, Wilson GDF (1993) Global-scale latitudinal patterns of species diversity in the deep-sea benthos. Nature 365:636-639

Ritzrau W (1994) Labor- und Felduntersuchungen zur heterotrophen Aktivität in der Bodennepheloidschicht. Ber Sonderforschungsbereich 313(47):1-99

Romero-Wetzel M, Gerlach S (1991) Abundance, biomass, size-distribution and bioturbation potential of deep-sea macrozoobenthos on the Voring Plateau (1200-1500 m, Norwegian Sea). Meeresforsch 33:247-265

Rothlisberg PC, Pearcy WG (1977) An epibenthic sampler to study the ontogeny of vertical migration of Pandalus jordani (Decapoda Caridea). Fish Bull US 74:994-997

Sanders IIL (1968) Marine benthic diversity: a comparative study. Am Nat 102:243-282

Sanders HL, Hessler RR, Hampson G R (1965) An introduction to the study of deep-sea benthic faunal assemblages along the Gay Head-Bermuda Transect. Deep Sea Res 12: $845-876$

Schneider W, Budéus G (1994) The North East Water Polynya (Greenland Sea). I. A physical concept of its generation. Polar Biol 14:1-9

Shannon CE, Weaver W (1949) The mathematical theory of comunication. Univ Illinois Press, Urbana

This article was submitted to the editor
Smith CR (1985) Food for the deep sea: utilization, dispersal, and flux of nekton falls at the Santa Catalina Basin floor. Deep Sea Res 32:417-422

Smith CR, Hamilton SC (1988) Epibenthic megafauna of the bathyal basin off Southern California: patterns of abundance, biomass, and dispersion. Deep Sea Res 30(9A): $907-928$

Smith SD, Muench RD, Pearse CH (1990) Polynyas and leads: an overview of physical processes and environment. J geophys Res 95:9461-9479

Smith WO, Walsh IB Jr, Booth BC, Deming J (1995) Particulate matter and phytoplankton biomass distributions in the Northeast Water Polynya: relationships to hydrography and nutrient distributions. J geophys Res 100 : $4341-4356$

Soetaert K, Heip C (1990) Sample-size dependence of diversity indices and the determination of sufficient sample size in a high diversity deep-sea environment. Mar Ecol Prog Ser 59:305-307

Suess E (1980) Particulate organic carbon flux in the oceans - surface productivity and oxygen utilization. Nature 288:260-265

Svavarsson J, Brattegard T, Strömberg J-O (1990) Distribution and diversity pattern of asellote isopods (Crustacea) in the deep Norwegian and Greenland Seas. Prog Oceanogr 24 : $297-310$

Svavarsson J, Gudmundsson G, Brattegard T (1993a) Feeding by asellote isopods (Crustacea) on foraminifers (Protozoa) In the deep sea. Deep Sea Res 40(6):1225-1239

Svavarsson J, Strömberg J-O, Brattegard T (1993b) The deepsea asellote (lsopoda, Crustacea) fauna of the Northern Seas: species composition, distributional patterns and origin. J Biogeogr 20:537-555

Vinje TE (1970) Sea ice observations in 1969. Arbok Norsk Polarinst 1969:132-138

Vinje TE (1984) The Fram Strait cruise with M/S Lance, August 1984. Norsk Polarinstitutt Rapportserie 18

Wadhams P (1981) The ice cover of the Greenland and Norwegian seas. Rev Geophys 19:345-393

Wainwright SC (1990) Sediment-to-water fluxes of particulate material and microbes by resuspension and their contribution to the planktonic food web. Mar Ecol Prog Ser 62: $271-281$

Wilkinson GN, Eckert SR, Hancock TW, Mayo O (1983) Nearest neighbour (NN) analysis of field experiments (with discussion). J R Stat Soc B 45:151-211

Manuscript first received: October 13, 1994

Revised version accepted: January 21, 1995 